\title{
開水路横断面内流速分布測定の自動化と $\mathrm{X}$ 型Hot-filmによる 2 次流測定值の補正
}

An automatic velocity measurements system operated by P.C.

: Velocity measurements for open channel flows

鬼束幸樹* ·浦 勝** 秋山專一郎*** 政徳克志***

By Koki ONITSUKA, Masaru URA, Juichiro AKIYAMA and Katsushi SEITOKU

\begin{abstract}
A P.C.-controlled automatic measuring system is developed for quantifying three-dimensional structure of open channel flows. Manual-controlled measuring systems require a great deal of time and labor as well as cause error in measurements. The proposed system allows us to obtain the velocity field of the considering flow with little manpower and high accuracy. In addition, an error inherent to spacing of two sensors, which usually occurs in measurements of velocity components by X-type Hot-film anemometer, is rectified on the basis of logarithmic velocity profile.
\end{abstract}

Keywords: open channel flow, velocity measuring system, secondary flow, Hot-film anemometer

\section{1 . はじめに}

開水路流れの 3 次元的構造を明らかにしたいという要求が、近年特に強まってきた。その理由は、従来の 河道安定という治水的観点のみならず、河道の持つ多様性が生態系保全に大きな寄与をもつ事を水理学的に 評価したいという環境的観点にあるといえよう。3次元構造を明らかにするためには、複倠な縦・横断面形 状をもつ水路内において、(1)測定器の検出部を正確に所定の位置と方向に移動し設置すること、及び(2)移 動・設置・計測の自動化を行い、操作労力を軽減化すると共に、誤操作の阻止を図る事が要求される。

開水路流の流速測定に関しては、従来よりPitot管, プロペラ流速計, Hot-film流速計，電磁流速計、さら に、1980年代より台頭してきたレーザードップラー流速計などによって行われてきた。この内、3次元 性を直接あるいは間接的に測定できるものはレーザードップラー流速計, Hot-film流速計，電磁流速計であ る。しかし、レーザードップラー流速計は非常に高価であり、電磁流速計は検出部の寸法が大きいため、小 型の実験水路では不向きである。Hot-film流速計は、一般に流速の 2 成分しか直接湘定する事はできないか、 プローブを $90^{\circ}$ 回転させて 2 回測定することにより3次元性が推定でき、その上に比較的安価で取り扱いが

$\begin{array}{llllll}* & \text { 学生員 } & & \text { 九州工業大学工学研究科博士前期課程 } & \text { （干804 北九州市戸畑区仙水町 1-1） } \\ * * & \text { 正会員 } & \text { 工博 } & \text { 九州工業大学工学部設計生産工学科 } & & \\ * * * & \text { 正会員 } & \text { Ph.D. } & \text { 九州工業大学工学部設計生産工学科 } & \\ * * * * & \text { 学生員 } & & \text { 九州工業大学工学研究科博士前期課程 } & \end{array}$


容易であるため、今後も重要な測定法の一つであると言えよう。

いずれの流速計を用いる場合も、従来は、測点間移動は人力に頼っているケースが多く、非常に人的労力 を要する上、流速計の位置 ·方向設定誤差や個人誤差、そして誤操作の危険性もあり精度は良くない。測定 誤差は特に2次流速に多大な影響を及ぼすが、流れの三次元構造を明らかにするためには高精度な2次流の 検出が必要である。そこで、著者らはステッピングモータを用いた検出部移動装置による流速の横断面内測 定の自動化を図った。ステッピングモータを用いた自動測定法は既に報告されている1)。しかし、従来から 報告されている自動化に際しては非常に高度な、しかも専門的な電子工学の知識を要する。一般にそのよう な高度で専門的な知識を取得する事は容易ではなく、従って自動計測の普及は立遅れているのが現状である。 本報告では電子工学の知識をあまり要しない具体的方法を示し、さらに自動測定装置を用いた開水路流測 定およびX型Hot-filmによって得られる2次流速の補正についても示す。これにより、自動測定法が普及し、 労力の軽隇、精度向上により水工学における研究がよりいっそう進展すれば幸いと考えている。

\section{2. 自動化の形態}

著者らは以前より、X型Hot-film流 速計による開水路流測定を行ってきた 2)。横断面内測定は数百に上る測定点 を有する。実験は計測と移動の繰り返 しであり、従来は測定点間移動を人力 に頼っていたため非常に多大な労力と 時間を必要とした。人力による測定で は長時間測定か吥可能なことや、誤差 を生じやすいなどの理由により、特に 2 次流速の測定結果の精度は余り良く なかった。

完全自動測定を完成させるためには、 計測系の自動化，検出部移動系の自動 化、そしてこの両者を管理する制御系 の自動化を行わなければならない。困 - 1にシステムの模式図を、表一 1 に 器具の名称を示す。システムの概略と

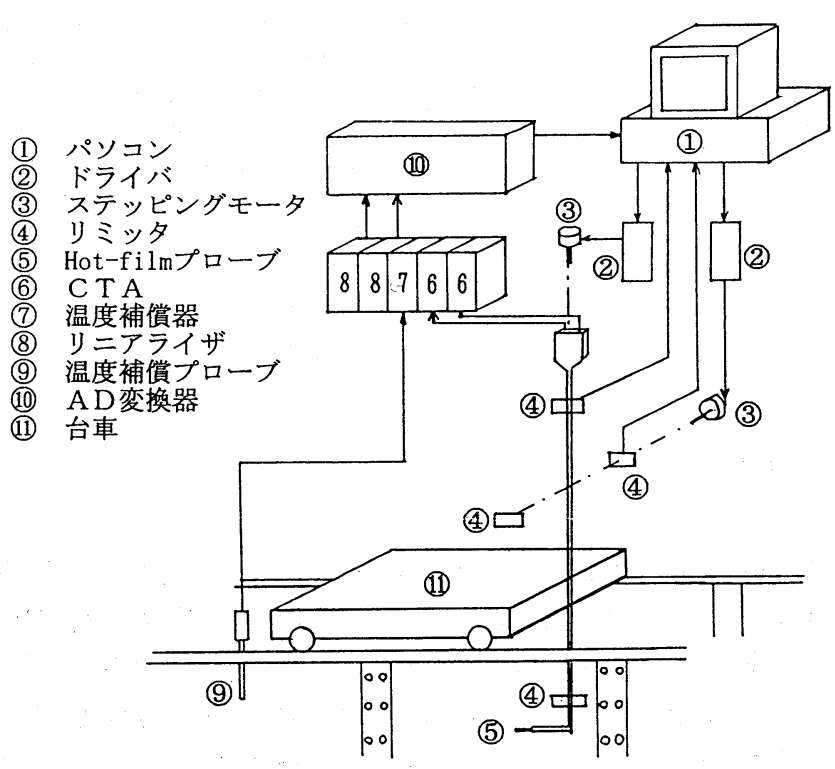

図一 1 システムの模式図

表- 1 器具の名称

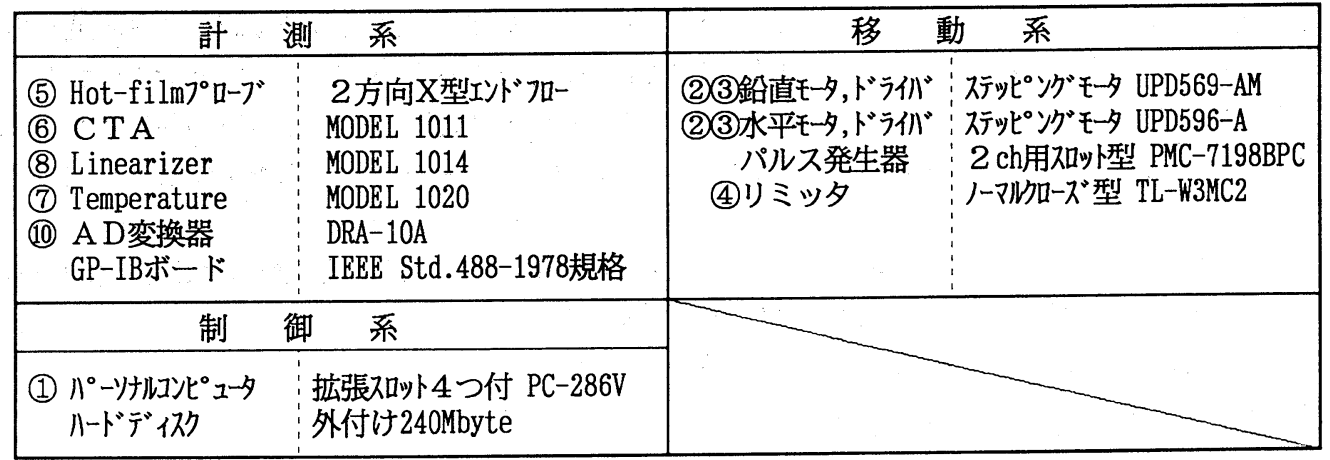


しては、水路上面に設置されたレールの上に台車11があり、その台車上に鉛直及び水平方向の移動用レール があり検出部(5)が平面的に動くようになっている。水路周辺にはC T A(6), A D 変換器(10, コンピュータ(1) などの測定機器が置かれている。検出部をのせた台車は、マニュアル操作で走行速度を変化さることが可能 であるため、流速計のキャリブレーションができるようになっている。

\section{1 計測系の自動化}

計測はHot-film流速計を用いた。計測の概要及びデー夕の流れは以下のようである。2方向Hot-filmプロ 一ブ(5)による流速の 2 成分の信号がC T A(6)より得られる。一方、水温計(9による水温変化を温度補償器7 により補正して、C T Aから得られた出力がリニアライザ8に送られる。リニアライザにより線形化された 2成分のアナログデータは $\mathrm{AD}$ 変換器(10に送られる。今回用いた $\mathrm{AD}$ 変換器は、パソコン(1)より $\mathrm{R} \mathrm{S}-23$ $2 \mathrm{C}$ また $\mathrm{GP}$ - I Bを介し制御が非常に簡単なT社製D R A - $10 \mathrm{~A}$ (10である。このAD変換器の性能は はサンプリング速度0.0005 32.767 sec、許容電圧は0〜16Vで、同時に1 0チャンネルまでの制御か可能であ り、各チャンネルは15360のデータをメモリに記憶することができる。サンプリング間隔を $0.002 〜 0.02 \mathrm{sec}$ ， データ数を8192個とする計測ならば、このAD変換器の性能は十分である。パソコン制御により、このAD 変換器からパソコンに送られてくるデジタルデータは外部記憶装置（ハードディスク）に保管される。

\section{2 検出部移動系の自動化}

開水路流の 3次元性を明らかにするためには、流速の水路横断 面内分布を測定し、その流下方向変化を調べなければならない。 そのため、プローブを鉛直方向及び横断方向に移動させる必要が ある。そこで、図一 1 に示す台車(11)上に鉛直方向及び水平方向の プローブ移動用レールとなるL Mガイドを設け、その軸とステッ ピングモータ(3)を連結させ、さらにドライバ(2)に接線した。ステ ッピングモータは通常のD Cサーボモータと異なり、小刻みな階 段状の回転をするが回転角度が非常に正確であり、またパソコン による制御が容易である。図ー2に示すように、パソコンの拡張 スロットに挿入されたパルス発生器からドライバに命令が伝えら れ、ステッピングモータを動かす仕組みになっている。

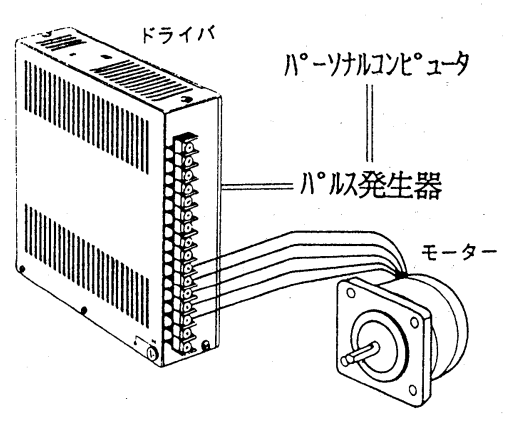

図一2 移動システム

何らかの原因でステッピングモータが誤動作をし、プローブが水路の壁面に衝突するなどへの安全対策と して、水面近傍, 底面近傍, 及び右岸・左岸近傍の移動端部の四力所にリミッ夕（図一1の(4) を取り付け た。モータが移動端部以上に回転しようとする場合、リミッタがそれを感知しパルス発生器に電気信号とし て伝えるので、パルス発生器はパソコンから送られてくる命令よりも優先的にモータを停止させる。再び逆 方向の回転命令がくればモータは逆方向の回転を開始するようになっている。リミッタにはノーマルオープ ン型 ( NO型) とノーマルクロース型 ( N C 型) があり、NO型は通常回路がオープンで電流が流れておら ず、リミッタが反応すると回路が閉じて電流が流れる。N C型はその逆である。どちらのリミッタを選ぶか は、リミッタを接続するパルス発生器に依存するので、あらかじめリミッタを購入する前にチェックすると 良い。今回用いたパルス発生器はNC用であった。

プローブの位置の確認には、モータの回転数により位置の確認が可能なエンコーダを用いるとよい。

以上の装置により所定の横断面内の測定点間移動が可能となり、移動部分の先端にHot-filmプローブを装 着すれば、横断面内流速測定が可能となる。

\section{3 制御系の自動化}

計測系は $\mathrm{AD}$ 変換器を $\mathrm{G} \mathrm{P}$ - I B 介行い、移動系はステッピングモータをパルス発生器を介して行 うが、それにはコントローラが必要となる。近年のパーソナルコンピュータは実験室のような劣悪な環境に も耐え、しかも高性能で低価格であり、コントローラとして最適である。 
実験を無人化するにはそれぞれの系でプログラムを組み、バッチ処理すればよいことになる。計測系及び 移動系プログラムは、GP－ＩＢボード及び拡張スロット用パルス発生器を購入するとサンプルプログラム が添付されてくるので、それらを参考にすれば比較的容易に組む事ができる。言語は今回、MS - D O S 版 コンパイラB A S I Cを用いた。コンパイラB A S I CはインタープリタB A S I Cより高速に動作するの で制御に適しているといえる。

一般に長時間の計測では、デー夕量も膨大になるが、これを保管するパソコンの外部記憶装置として、現 在、比較的安価で大容量のハードディスクが適している。また、プログラム作業領域としてR AMD I S K があると非常に便利である。このために、パソコンの拡張スロットを 4 用いる事となった。つまり、パル ス発生器, RAMボード, ハードディスクインターフェースボード, GP－I Bボードである。パソコンは 拡張スロットの数の面から、ノート型よりディスクトップ型の方が良いと思われる。

\section{X型Hot-film流速計による自動測定}

前述した自動測定装置を用いて、X型Hot-film流速計による横断面内流速測定を行った。実験方法及び実 験結果について述へ、従来X型Hot-filmでは測定が非常に困難な2 次流 ${ }^{3)}{ }^{4)}$ 及びその補正についても述べる。

\section{1 実験方法}

実験に用いた水路は、水路幅 $60.0 \mathrm{~cm}$, 長さ $2050 \mathrm{~cm}$ 可変勾配水路である2)。実験条件は流量 $9300 \mathrm{cc} / \mathrm{s}, 下$ 流端水深 $13.5 \mathrm{~cm}$ ，水路床勾配 $1 / 10000$ で測定位置は水路入口より流下方向に $\mathrm{x}$ 軸をとり、 $\mathrm{X}=1300 \mathrm{~cm}$ とした。た だし、文献2)で見られるように、400<X<600 cmは水路幅は $19.6 \mathrm{~cm} て ゙ 、 600<X<1100 \mathrm{~cm}$ は緩やかにかつ直線的に水

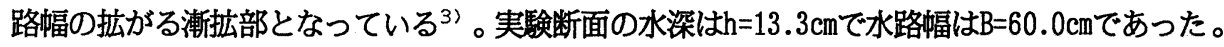

主流流下方向に $\mathrm{x}$ 軸を, 水路床を原点として鉛直上向き に $\mathrm{y}$ 軸を、 $\mathrm{x}, \mathrm{y}$ 軸に直角に側壁を原点として $\mathrm{z}$ 軸をとる。 測定位置は $\mathrm{y}-\mathrm{z}$ 平面の、主に右岸側の $23 \times 22$ 個のそれぞ れの格子点においてX型Hot-film流速計を 2 度使用する事 により、 $\mathrm{U}-\mathrm{V}$ 及び $\mathrm{U}-\mathrm{W}$ 流速値が得られる。但し、 $\mathrm{x}$, $\mathrm{y}, \mathrm{z}$ 方向の流速をそれぞれU，V，Wとし、サンプリン グ間隔は0.01sec, サンプリング時間は81.92secとした。ま た、X型Hot-filmプローブの概略図を図ー3に示し、今回 用いたKanomax 1241-60Wの寸法を表ー2に示した。ただし、 2本のセンサ間隔をsとしている。図一 3 には括弧無し記 述と、括弧付きの記述があるが、括弧無しは測定中にプ ローブを水路上面からみるとX型をしているU－W測定で、 括弧付きはプローブを水路側面からみるとX型をしている U-V測定を示している。X型Hot-filmプローブは互いに 直行する 2 本のセンサがx軸と士45をなすようにプロン

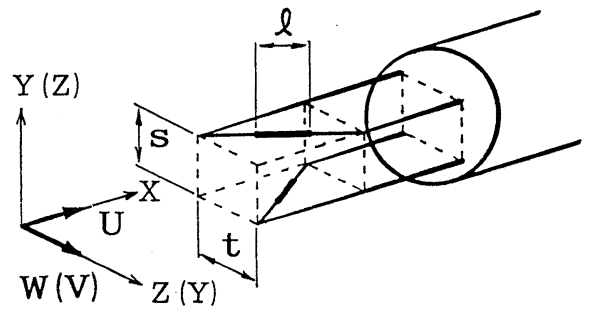

図一－X型Hot-filmの概略図

表-2 Kanomax 1241-60Wの仕様

\begin{tabular}{|c|c|c|c|}
\hline 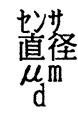 & $\begin{array}{c}\text { 誓さ } \\
\text { mm } \\
\iota \\
\iota\end{array}$ & 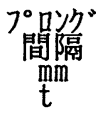 & $\begin{array}{c}\text { 战簡隔 } \\
\mathrm{mm} \\
\mathrm{S}\end{array}$ \\
\hline 152 & 2.0 & 3.5 & 1.0 \\
\hline
\end{tabular}
グ間に張られていて、受感部はその中央部分であり、困ー3ではそれを明示する為に太く示している。

\section{2 実絤結果及ひ補正}

2次流すなわち、主流に直角方向の流速成分 V , Wの大きさはX型の各々のセンサからの出力の差として 得られる。図ー3において、座標軸が括弧無しの場合のようにプローブを設置した場合を考えれば、各々の センサから得られる出力值を $\mathrm{e}_{1}, \mathrm{e}_{2}$ とすると、 z方向すなわち水路横断方向の流速成分Wの值は、一般に

$$
W=\frac{e_{1}-e_{2}}{2}
$$


となる。しかし、図-4 (a)に示ように、U-W浿定においては、プローブのセンサ間隔のため $\mathrm{e}_{1}, \mathrm{e}_{2}$ は主 流速分布による偏差を含んでいる。この偏差は、速度勾配の急な底面近傍及び側壁近傍で非常に大きくなる。

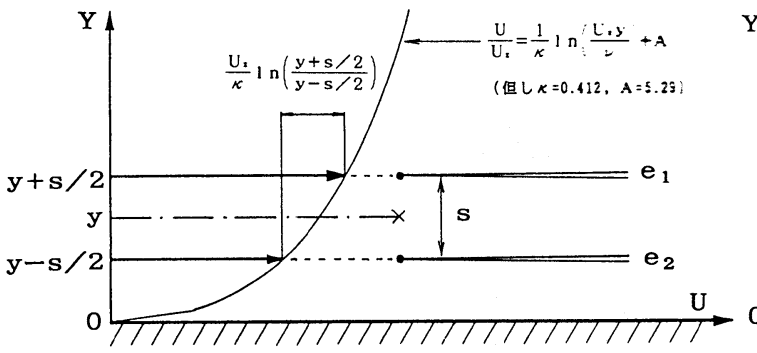

図-4(a) U-W測定状況

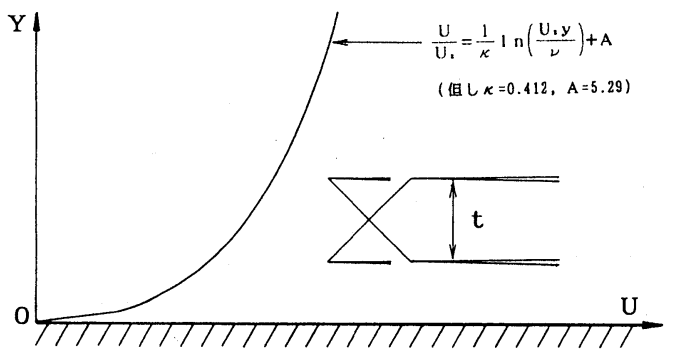

(b) $U-V$ 測定状况

図-4 (b)に示す U-V測定は2本のセンサーの受感部が底面から等距離にあるため、そのような偏差は含ま れない。従って主流速Uの鉛直分布は、図-4 (a)に示すU-W測定より、困-4(b)に示すU-V測定の方 が信憑性か高いため、U - V測定より得られる流速值を用い、次式の対数則より摩擦速度U *を決定した。

$$
\frac{\mathrm{U}}{\mathrm{U}_{*}}=\frac{1}{\kappa} \ln \left(\frac{y \mathrm{U}_{*}}{\nu}\right)+\mathrm{A}
$$

たたし、КはKarman定数，Aは 積分定数、レは動粘性係数であ り、 $\kappa=0.412, A=5.29$ とした そこで、U-W測定時も $\mathrm{U}-\mathrm{V}$ 測定時と同様の流速分布である と仮定し、センサ間隔 $\mathbf{S に よ る ~}$ 補正を以下の式で行った。

$W=\frac{e_{1}-e_{2}}{2}$

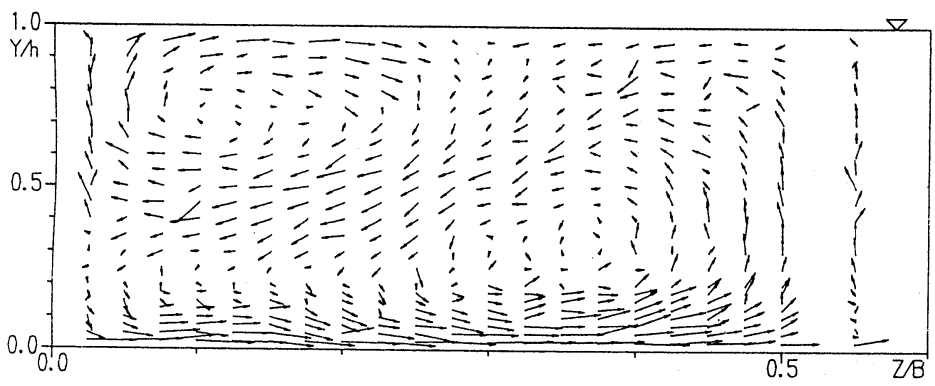

$-\frac{U_{*}}{2 \kappa} \ln \left(\frac{\mathrm{y}+\mathrm{s} / 2}{\mathrm{y}-\mathrm{s} / 2}\right)$

図－5（a）連続条件による補正のみによる2次流ベクトル図

また、V成分の補正もW成分 と同様に、壁面より水路中央部 に向かう流速分布をU-W測定 による対数則によって行う。セ ンサ間隔の補正を行った後、従 来から行われている次式の連続 条件を満たすように補正した6)。

$$
\begin{aligned}
& \int_{0}^{B / 2} V d z=0 \\
& \int_{0}^{h} W d y=0
\end{aligned}
$$

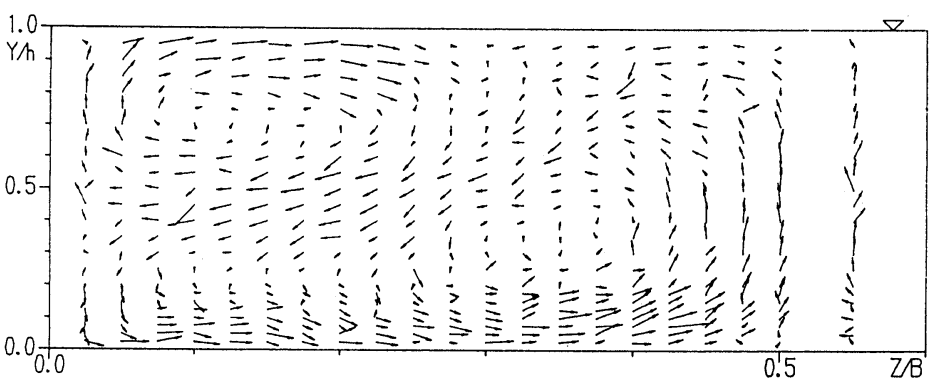

\section{連続条件による補正のみを行っ}

た2次流ベクトルを図ー5 (a)に、センサ間隔を考慮した補正及び連続条件による補正後の 2 次流速ベクトル を図ー $5(\mathrm{~b})$ に示す。水路中央の $\mathrm{z} / \mathrm{B}=0.5$ ではW $\fallingdotseq 0$ となるはずたが、図 $-5(\mathrm{a})$ を見ると底面近傍でかなり大き 
なW成分を持っている。しかし、図一 $5(\mathrm{~b})$ を見ると $\mathrm{z} / \mathrm{B}=0.5$ においてW $\fallingdotseq 0$ となっており、壁面近傍における X型Hot-film流速計による2次流成分の測定值にはセンサ間隔を考慮した補正が必要なことがわかった。

\section{4. おわりに}

以上、ステッピングモータを用いたX型Hot-film流速計による開水路流測定の自動化の具体的方法、及び 開水路横断面内 2 次流の補正について述べた。この自動計測装置によってサンプリング間隔 $0.01 \mathrm{sec}$, サンプ リング時間81.92secの流速測定を鉛直，水平方向にHot-filmプローブを移動させて行い、 $23 \times 22=506$ 点の測 定をおおよそ 16 時間で行うことができ能率と精度が飛躍的に向上した。本実験テー夕は合計約 6 8Mbytes であり、ハードディスクに保存後、流速値に変換する。本システムは流速計の検定を除けば無人のため、昼 夜を問わず 24 時間の測定が可能であり、24時間測定を連続的に行う場合は同様のハードディスクとパソ コンをもう一台用意し、それらを交換しながら測定を行えば、測定と流速変換を同時進行できてさらに効率 がよくなる。また、X型Hot-filmプローブの形状を考慮し2次流の補正を行ったが、乱れ強度, Reynolds応 力等の補正も今後考慮しなければならないと考えている7)。本文ではHot-film流速計による自動測定につい て述べたが、その他の流速計や濃度測定器についても同様のことがいえよう。本研究が水工学における自動 測定に寄与する事ができれば幸いである。

\section{謝辞}

自動化の有効性を示唆していただいた本学工学部、久保喜延助教授及び加藤九州男助手に、また、Hot-fi $1 \mathrm{~m}$ 特性に関し文献の提供及び貴重な意見をいたたいた神戸大学工学部、中山昭彦助教授に感謝の意を表し ます。最後に本文中の開水路流実験で協力いただいた卒論生、岡本実, 松岡定和の両氏に謝意を表します。

\section{参 考文 献}

1）藤田裕一郎, 澤井健二 : 移動床水理実験におけるラボラトリー・オートメーションの試み; 水工学論文 集 第 34 巻, pp.701-706, 1990

2）鬼束幸樹, 浦 勝, 政徳克志 : 漸拡開水路流の乱れエネルギ一輸送 ; 第 48 回年次学術講演会概要集, pp.740-741, 1993

3）浦 勝, 秋山壽一郎, 久保大介, 山本一 : 漸拂長方形断面開水路流の乱れについて; 水工学論文集 第 34 巻, pp.451-456, 1990

4）浦 勝, 秋山壽一郎, 川崎淳一郎, 鬼束幸樹 : 渐拡長方形断面開水路流の流況変化について; 水工学論 文集 第3 6 巻, pp.379-384, 1992

5) Iehisa Nezu and Wolfgang Rodi:Open-Channel Flow Measurements with a Laser Doppler Anemometer, Journal of Hydraulic Engineering, Vol.112, No.5, May, pp.335-355, 1986

6）冨永晃宏, 江崎一博 : 長方形断面開水路流の三次元乱流構造に関する実験的研究; 土木学会論文集 第 357号/II-3 , pp.81-88, 1985

7) Akihiko Nakayama and Russell V.Westphal:The Effects of Sensor Length and Spacing on X-Wire Measurements in a Boundary Layer, NASA Technical Memorandum 88352, pp.1-10, 1986 